Musters, A.M., Twisk, M., Leschot, N.J., Oosterwijk, C., Korevaar, J.C., Repping, S., Veen, F. vąn der, Goddijn, M. Perspectives of couples with high risk of transmitting genetic disorders.

Fertility and Sterility: 2010, 94(4), 1239-1243

\begin{tabular}{|l|l|}
\hline $\begin{array}{l}\text { Postprint } \\
\text { Version }\end{array}$ & 1.0 \\
\hline $\begin{array}{l}\text { Journal website } \\
\text { Pubmed link }\end{array}$ & $\underline{\text { http://www.fertstert.org/article/S0015-0282(09)03488-8/abstract }}$ \\
\hline DOI & $\underline{\text { http://www.ncbi.nlm.nih.gov/pubmed/19815189 }}$ \\
\hline
\end{tabular}

This is a NIVEL certified Post Print, more info at http://www.nivel.eu

\title{
Perspectives of couples with high risk of transmitting genetic disorders
}

AnNa M. Musters M.D..$^{A}$, MONIEK TWISK M.D. ${ }^{A}$, NiCO J. LeSCHOt M.D., PH.D. ${ }^{B}$, COR

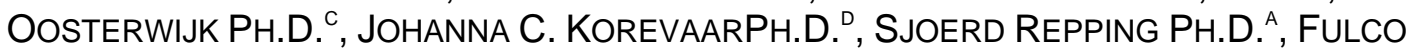
VAN DER VEEN M.D., PH.D. ${ }^{A}$ AND MARIETTE GODDIJN PH.D. ${ }^{A}$

${ }^{a}$ Center for Reproductive Medicine, Department of Obstetrics and Gynecology, Academic Medical Center, University of Amsterdam, Amsterdam, the Netherlands

${ }^{\mathrm{b}}$ Department of Clinical Genetics, Academic Medical Center, University of Amsterdam, Amsterdam, the Netherlands

${ }^{c}$ Dutch Genetic Alliance VSOP, Soest, the Netherlands

d Department of Clinical Epidemiology, Biostatistics and Bioinformatics, Academic Medical Center University of Amsterdam, Amsterdam, the Netherlands

Objective To investigate the preference for preimplantation genetic diagnosis (PGD) as an alternative to prenatal diagnosis (PND) in a large group of couples representing a wide array of genetic disorders. We also investigated the couple's familiarity with PGD and presented time trade-off scenarios for PGD versus PND, as PGD treatment is regularly accompanied by waiting lists.

Design Questionnaire study.

Setting Patient organizations representing genetic disorders.

Patient(s) A total of 210 couples carrying genetic disorders.

Main Outcome Measure(s) Preference for PGD or PND and familiarity with PGD in carrier couples.

Result(s) Fifteen organizations representing 38 genetic disorders agreed to participate. Nine hundred eighty-three couples responded. In total 210 couples were in their reproductive years (women 18-40 years) and had a desire to conceive. Ninety couples (42\%) had never heard of PGD. After they were informed, 127 couples (60\%) wanted to have diagnostic testing (PND or PGD) performed. Ninety-four (74\%) of these couples preferred testing with PGD. When no waiting list was used 102 couples (80\%) preferred PGD. With a 2-year waiting list for PGD, 58 couples (46\%) would opt for PGD.

Conclusion(s) Many carrier couples are unaware of the existence of PGD. When informed, most couples prefer PGD more than PND. The preference for PGD decreases with longer waiting lists.

Since its introduction in 1990, preimplantation genetic diagnosis (PGD) has been used as an alternative for invasive prenatal diagnosis (PND) to avoid pregnancy termination in couples at high risk of transmitting genetic disorders (1). The PGD implies the use of IVF to obtain embryos. A single cell of each embryo is aspirated, and its nuclear DNA is assessed for the specific genetic disorder. 
Musters, A.M., Twisk, M., Leschot, N.J., Oosterwijk, C., Korevaar, J.C., Repping, S., Veen, F. vąh der, Goddijn, M. Perspectives of couples with high risk of transmitting genetic disorders.

Fertility and Sterility: 2010, 94(4), 1239-1243

Prenatal diagnosis is widely accessible and is applied in the first trimester of pregnancy. This approach rests largely on the acceptability of selective termination of pregnancy, which is a stressful and traumatic experience (2), (3), (4) and (5). For a couple, the grief following termination of pregnancy for a fetal abnormality can be similar to the grief following neonatal death (6). In addition, there is a $0.3 \%-0.4 \%$ risk of procedure-related miscarriage after PND (7) and (8).

Before the introduction of PGD, carriers of genetic disorders had the option of childlessness, adoption, gamete donation, termination of pregnancy after a negative PND result, or playing "reproductive roulette" (9).

Preimplantation genetic diagnosis provides couples the chance of an unaffected genetically related child without the need to consider pregnancy termination. In practice PGD is not an easy solution. There are widely recognized physical and emotional burdens involved in IVF such as the complications of IVF treatment itself (i.e., ovarian hyperstimulation syndrome and the risks associated with a follicle aspiration) and the increased risk of neonatal morbidity and mortality mostly as a result of a twin pregnancy (10), (11) and (12). In addition to the risks and complications related to IVF, the access of PGD is currently restricted in many countries (13). The clinical pregnancy rate (PR) per ovum pick-up for IVF with PGD is on average 22\% (14).

Data on the preference for PGD compared with PND in carrier couples are conflicting. Five preference studies investigating the preference of PGD compared with PND reported that PGD was slightly more preferred than PND. However, these studies included a limited number of couples with a limited amount of genetic disorders (15), (16), (17), (18) and (19). On the other hand, one large study showed a 30\% preference for PGD. In that study PGD was not solely compared with PND but also to adoption, donor insemination, and oocyte donation in carrier couples (20).

Considering the increasing number of PGD cycles performed worldwide (14) we wanted to investigate the current preference for PGD as an alternative to PND in a large group of couples representing a wide array of genetic disorders. We also investigated the familiarity with PGD in these couples and presented time trade-off scenarios, as PGD is regularly accompanied by waiting lists.

\section{MATERIALS AND METHODS}

A self-report questionnaire study was set up as a collaborative study from the Academic Medical Center in Amsterdam and a joint patient organization for patients with genetic disorders VSOP. The questionnaire was designed by two authors M.T. and J.K. Both have experience in designing questionnaire studies (21), (22) and (23).

Patient organizations representing genetic disorders with a PGD indication (e.g., neurofibromatosis, cystic fibrosis, Morbus Huntington) (Table 1) were contacted to participate, from January-September 2007, first by e-mail and if the organization did not reply it was contacted by telephone. When participation was agreed upon, questionnaires were sent to the organization either by mail or electronically. The organization distributed the questionnaires by mail to their members or the questionnaire was uploaded on the organization's Website where members could retrieve it. The VSOP also posted the questionnaire on their Website. It was agreed to send the questionnaire only once, as not to burden the couples.

\section{[TABLE 1]}

The questionnaire included a letter explaining the purpose of the study and information on PND and PGD procedures (Addendum 1 contains a translated version of the information provided on PND and PGD in the questionnaire). On each questionnaire contact information for general inquiries was given. Institutional review board (IRB) approval was not needed 
Musters, A.M., Twisk, M., Leschot, N.J., Oosterwijk, C., Korevaar, J.C., Repping, S., Veen, F. vąh der, Goddijn, M. Perspectives of couples with high risk of transmitting genetic disorders. Fertility and Sterility: 2010, 94(4), 1239-1243

because a questionnaire study is not subject to the Dutch "Medical Research Involving Human Subjects Act.”

The questionnaire itself was divided into four categories. The first part of the questionnaire collected general data on the subjects including their age, genetic disorder, obstetric history, history of termination of an affected pregnancy, and previous experience of PGD or PND. The second part of the questionnaire focused on the couple's familiarity with PGD.

To assess current preference for PGD and PND we were interested in couples who were facing the choice of testing at this moment or in the near future. Therefore, in the third part of the questionnaire couples were asked whether they wanted to conceive now or in the future. If this was answered positively, they were asked whether they were considering a diagnostic test and, if so, whether they preferred PGD or PND. Couples were also given choice options in case they opted for either PGD or PND. Choice options are presented in Table 2.

\section{[TABLE 2]}

To assess whether a couple's preference was influenced by waiting time, the last part of the questionnaire presented different waiting list scenarios, ranging from no waiting list to a 2year waiting list.

\section{RESULTS}

\section{Questionnaires}

Forty-two patient organizations representing various genetic disorders with PGD indications were contacted and 15 organizations, representing 38 genetic disorders, agreed to participate (Table 1). Reasons for not participating in this survey were as follows: organizations were not interested or thought that their members would not be interested, organizations did not want to burden their members, had insufficient manpower or time to distribute questionnaires, and two organizations were recently disbanded. Of the 15 participating organizations, 10 distributed the questionnaires by mail to all active members and five placed the questionnaires on their Website. In total, these 15 organizations distributed 2,692 questionnaires by mail and 953 questionnaires were returned (response rate $35 \%)$. Twenty-six questionnaires were returned after placement on the specific organization's Website and an additional four questionnaires were returned from the VSOP website. This resulted in a total of 983 questionnaires returned, of which 960 were valid for data extraction.

\section{Baseline Characteristics and Obstetric History}

Of all 960 valid questionnaires returned, 407 couples were in their reproductive years, defined as women 18-40 years old. One hundred ninety-seven of these couples did not want to conceive for various reasons: their family was complete, scared for a child with a genetic disorder, no desire for a child ever, pregnancy is not possible with their specific genetic disorder. The 210 couples who did want to conceive represented 28 genetic disorders. Baseline characteristics and obstetric history are shown in Table 3. Of these couples, 169 previous pregnancies were achieved, which resulted in 51 (30\%) affected children, 49 (29\%) unaffected children, and 49 (29\%) children who were not yet tested for the genetic disorder. Six pregnancies (4\%) had been terminated and in 14 cases (8\%), pregnancy outcome was not filled in by the parents. In 22 cases the couples had chosen genetic tests (5 PGD and 17 PND) (Table 3). 
Musters, A.M., Twisk, M., Leschot, N.J., Oosterwijk, C., Korevaar, J.C., Repping, S., Veen, F. vąn der, Goddijn, M. Perspectives of couples with high risk of transmitting genetic disorders.

Fertility and Sterility: 2010, 94(4), 1239-1243

\section{[TABLE 3]}

\section{Familiarity with PGD}

Four hundred ninety-five couples (52\%) with a genetic disorder had never heard of PGD. When focusing only on couples in their reproductive years (210) with a desire to conceive, 90 (42\%) had never heard of PGD (Table 4). One hundred fifty (71\%) couples stated that their physician had not informed them about PGD.

[Table 4]

\section{Preference for PND/PGD}

One hundred twenty-seven couples (60\%) wanted diagnostic testing performed in a future pregnancy. The couples who did not want diagnostic testing in a subsequent pregnancy stated that any child (with or without a genetic disorder) would be welcome, or that they believed that their specific genetic disorder was not severe enough for diagnostic testing or gave no comment on the reason why they did not want testing. Ninety-four $(74 \%)$ of the couples who wanted testing preferred PGD as a diagnostic test (Table 1). The majority (51 couples; 54\%) of the couples who preferred PGD more than PND did so because they objected to termination of pregnancy (Table 2). The main reason for preferring PND more than PGD was that the couple did not want an IVF treatment (Table 4). Other reasons were that the couple believed that they did not know enough about PGD to make a decision, low PRs, waiting lists, the distance to the center offering PGD, and not wanting embryo testing.

\section{Time Trade-off}

In a scenario without waiting lists 102 couples (80\%) would opt for PGD. However, a 2year waiting list for a PGD treatment made the preference for PGD drop to 58 couples (46\%) (Addendum 2.;Table 5).

\section{DISCUSSION}

Our study showed a low awareness of PGD in couples with a high risk of transmitting a genetic disorder. In the target group, namely couples in their reproductive years and with a desire to conceive, $42 \%$ had never heard of PGD. This study also showed that when informed, $74 \%$ of the couples who would opt for testing would prefer PGD more than PND. The preference for PGD was influenced by waiting time trade-off; a waiting list of 2 years lowered the preference for PGD to $46 \%$.

This is the first time the familiarity with PGD has been studied in a large number of couples with a high risk of transmitting a genetic disorder. Also, the couples included had not been approached by a clinic offering diagnostic testing, as in prior studies. Therefore this study represents couples from all walks of life and is a good representation of the group as a whole, due to the large number and the various indications that were investigated.

Our study has a number of limitations that may affect the generalizability of the results. First, to guarantee anonymity of the patients, the questionnaires were sent to the patient organization that distributed the questionnaires themselves, making it difficult to single out the target group, namely couples in their reproductive years and with a desire to conceive. This explains the large number of questionnaires that could not be used for analysis. Second, we do not have information about those who did not participate in the study, thus we cannot comment on, or control for, nonresponse bias. Third, of 2,692 questionnaires that were distributed, 953 questionnaires were returned by the post office (35\% response rate). Because follow-up could not be used considering that the patient contact information was kept anonymous could explain this low response rate. Another reason for the low response rate could be that the couples have no affiliation with the Academic Medical Center in Amsterdam or a joint patient organization for patients with genetic disorders (VSOP) and therefore did not take the time to return the completed questionnaire.

In this study the preference for PGD (74\%) is higher than reported in existing scientific literature, where the reported preferences lies between $30 \%$ and 55\% (15), (16), (17), (18), 
Musters, A.M., Twisk, M., Leschot, N.J., Oosterwijk, C., Korevaar, J.C., Repping, S., Veen, F. vąm der, Goddijn, M. Perspectives of couples with high risk of transmitting genetic disorders. Fertility and Sterility: 2010, 94(4), 1239-1243

(19) and (20). The higher preference for PGD in our study group could be because most studies on this topic were performed more than a decade ago, at that time IVF-PGD was not as accessible. Also, IVF is an established and accessible treatment, reimbursed by the health insurance companies in the Netherlands. Lastly, our study population included couples who had not been approached by a clinic offering diagnostic testing, as in prior studies. Therefore our study shows a perspective from a possibly different group, namely couples from all walks of life with a high risk of conceiving a child with a genetic disorder and therefore it is a good representation of the group as a whole.

This study investigated time trade-off, as in most countries PGD is regularly accompanied by waiting lists caused by government restriction and the technical aspects of PGD, whereas PND is readily available. Therefore waiting list scenarios for PGD are a part of real life decision making and we wanted to investigate the time factor with respect to the preference for diagnostic testing. Our results show that indeed the preference of PGD is lowered when the waiting list increases to 2 years.

In couples with a risk of transmitting a genetic disorder, the knowledge of PGD was unexpectedly low. An explanation could be the insufficient knowledge or counseling by professional caregivers, considering that $71 \%$ (150/210) of these couples stated that their physicians had not informed them about PGD.

Although there are a number of limitations of this study, three important results emerge. First, $42 \%$ of the couples with a high risk of transmitting a genetic disorder, in their reproductive years and with a desire to conceive, had not previously heard about PGD. Therefore couples carrying genetic disorders should be counseled about both PND and PGD. Second, after giving information on the procedures, $74 \%$ of all couples at risk of transmitting a genetic disease preferred PGD more than PND. This was a higher percentage than was assessed a decade ago. Third, the preference for PGD is negatively influenced by waiting list scenarios. In view of this high preference, PGD should be readily available.

\section{REFERENCES}

1 A.H. Handyside, E.H. Kontogianni, K. Hardy and R.M. Winston, Pregnancies from biopsied human preimplantation embryos sexed by Y-specific DNA amplification, Nature 344 (1990), pp. 768-770.

2 B.D. Blumberg, M.S. Golbus and K.H. Hanson, The psychological sequelae of abortion performed for a genetic indication, Am J Obstet Gynecol 122 (1975), pp. 799-808.

3 P. Donnai, N. Charles and R. Harris, Attitudes of patients after "genetic" termination of pregnancy, Br Med J 282 (1981), pp. 621-622.

4 J. Lloyd and K.M. Laurence, Sequelae and support after termination of pregnancy for fetal malformation, Br Med J 290 (1985), pp. 907-909.

5 R.B. Black, A 1 and 6 month follow-up of prenatal diagnosis patients who lost pregnancies, Prenat Diagn 9 (1989), pp. 795-804.

6 S.L. Kenyon, G.A. Hackett and S. Campbell, Termination of pregnancy following diagnosis of fetal malformation: the need for improved follow-up services, Clin Obstet Gynecol 31 (1988), pp. 97-100.

7 P.S. Heckerling and M.S. Verp, Amniocentesis or chorionic villus sampling for prenatal genetic testing: a decision analysis, J Clin Epidemiol 44 (1991), pp. 657-670.

8 S. Elias and J.L. Simpson, Amniocentesis and fetal blood sampling. In: A. Milunsky, Editor, Genetic disorders and the fetus, John Hopkins University Press, Baltimore (2004), pp. 6699.

9 J.F. Fletcher, The ethics of genetic control: ending reproductive roulette, Prometheus Books, Buffalo, NY (1998).

10 L.A. Schieve, S.F. Meikle, C. Ferre, H.B. Peterson, G. Jeng and L.S. Wilcox, Low and very low birth weight in infants conceived with use of assisted reproductive technology, $\mathrm{N}$ Engl J Med 346 (2002), pp. 731-737.

11 M. Hansen, J.J. Kurinczuk, C. Bower and S. Webb, The risk of major birth defects after intracytoplasmic sperm injection and in vitro fertilization, N Engl J Med 346 (2002), pp. 725-730. 
Musters, A.M., Twisk, M., Leschot, N.J., Oosterwijk, C., Korevaar, J.C., Repping, S., Veen, F. vąn der, Goddijn, M. Perspectives of couples with high risk of transmitting genetic disorders.

Fertility and Sterility: 2010, 94(4), 1239-1243

12 A.K. Ludwig, A.G. Sutcliffe, K. Diedrich and M. Ludwig, Post-neonatal health and development of children born after assisted reproduction: a systematic review of controlled studies, Eur J Obstet Gynecol Reprod Biol 127 (2006), pp. 3-25.

13 Corveleyn A, Zika E, Morris M, Dequeker E, Lawford Davies J, Sermon K, et al. Preimplantation genetic diagnosis in Europe. European Commission; Joint Research Centre; Institute for Prospective Technological Studies. Published in Spain by the office for official Publications of the European Communities 2008 ISBN 978-92-79-05654-3.

14 V. Goossens, G. Harton, C. Moutou, P.N. Scriven, J. Traeger-Synodinos and K. Sermon et al., ESHRE PGD Consortium data collection VIII: cycles from January to December 2005 with pregnancy follow-up to October 2006, Hum Reprod 23 (2008), pp. 2629-2645.

15 M.L. Palomba, G. Monni, R. Lai, G. Cau, G. Olla and A. Cao, Psychological implications and acceptability of preimplantation diagnosis, Hum Reprod 9 (1994), pp. 360-362. View Record in Scopus | Cited By in Scopus (26)

16 E. Pergament, Preimplantation diagnosis: a patient perspective, Prenat Diagn 11 (1991), pp. 493-500.

17 S. Chamayou, A. Guglielmino, A. Giambona, S. Siciliano, G. Di Stefano and G. Scibilia et al., Attitude of potential users in Sicily towards preimplantation genetic diagnosis for betathalassaemia and aneuploidies, Hum Reprod 13 (1998), pp. 1936-1944.

18 S.A. Lavery, R. Aurell, C. Turner, C. Castellu, A. Veiga and P.N. Barri et al., Preimplantation genetic diagnosis: patients' experiences and attitudes, Hum Reprod 12 (2002), pp. 2464-2467.

19 P.W. Hui, Y.H. Lam, M. Chen, M.H. Tang, W.S. Yeung and E.H. Ng et al., Attitude of atrisk subjects towards preimplantation genetic diagnosis of alpha- and beta-thalassaemias in Hong Kong, Prenat Diagn 22 (2002), pp. 508-511.

20 C. Snowdon and J.M. Green, Preimplantation diagnosis and other reproductive options: attitudes of male and female carriers of recessive disorders, Hum Reprod 12 (1997), pp. 341-350.

21 M. Twisk, F. van der Veen, S. Repping and M.J. Heineman, Preferences of subfertile women regarding elective single embryo transfer: additional in vitro fertilization cycles are acceptable, lower pregnancy rates are not, Fertil Steril 88 (2007), pp. 1006-1009.

22 M. Twisk, M.L. Haadsma, F. van der Veen, S. Repping, S. Mastenbroek and M.J. Heineman et al., Preimplantation genetic screening as an alternative to prenatal testing for Down syndrome: preferences of women undergoing in vitro fertilization/intracytoplasmic sperm injection treatment, Fertil Steril 88 (2007), pp. 804-810.

23 M.T. Franssen, J.C. Korevaar, F. van der Veen, K. Boer, N.J. Leschot and M. Goddijn, Management of recurrent miscarriage: evaluating the impact of a guideline, Hum Reprod 22 (2007), pp. 1298-1303.

A.M.M. has nothing to disclose. M.T. has nothing to disclose. N.J.L. has nothing to disclose. C.O. has nothing to disclose. J.C.K. has nothing to disclose. S.R. has nothing to disclose. F.v.d.V. has nothing to disclose. M.G. has nothing to disclose. 
Musters, A.M., Twisk, M., Leschot, N.J., Oosterwijk, C., Korevaar, J.C., Repping, S., Veen, F. vąm der, Goddijn, M. Perspectives of couples with high risk of transmitting genetic disorders.

Fertility and Sterility: 2010, 94(4), 1239-1243

\section{TABLES}

Table 1

\begin{tabular}{|c|c|c|c|c|c|c|}
\hline \multicolumn{7}{|c|}{ Questionnaires received from couples with high risk for transmitting genetic disorders. } \\
\hline Genetic disorder & $\begin{array}{c}\text { Patient } \\
\text { organization }\end{array}$ & $\begin{array}{c}\text { Questionnaires } \\
\text { sent }\end{array}$ & $\begin{array}{l}\text { Questionnaires } \\
\text { returned }\end{array}$ & $\begin{array}{c}\text { Reproductive } \\
\text { age } \\
\text { and desire } \\
\text { to conceive }\end{array}$ & $\begin{array}{l}\text { Diagnostic } \\
\text { tests }\end{array}$ & $\begin{array}{l}\text { Prefer } \\
\text { PGD }\end{array}$ \\
\hline $\begin{array}{l}\text { Neurofibromatosis-1 } \\
\text { and }-2\end{array}$ & $\begin{array}{l}\text { Dutch Neurofibromatosis } \\
\text { organization }\end{array}$ & 850 & 309 & 44 & 34 & 23 \\
\hline $\begin{array}{l}\text { Retina pigmentosis, } \\
\text { retina dystrophy, } \\
\text { Usher syndrome, } \\
\text { Leber syndrome, } \\
\text { Norrie disease, } \\
\text { choroideremia }\end{array}$ & Dutch Retina organization & 500 & 205 & 39 & 22 & 17 \\
\hline Phenylketonuria & $\begin{array}{l}\text { Dutch Phenylketonuria } \\
\text { organization }\end{array}$ & 500 & 115 & 34 & 11 & 9 \\
\hline Marfan syndrome & Dutch Marfan organization & 280 & 130 & 30 & 18 & 15 \\
\hline $\begin{array}{l}\text { Crouzon syndrome, } \\
\text { Goldenhar syndrome, } \\
\text { Treacher Collins } \\
\text { syndrome, Cohen } \\
\text { syndrome, }\end{array}$ & Laposa & 232 & 86 & 14 & 7 & 5 \\
\hline $\begin{array}{l}\text { Familial adenomatous } \\
\text { polyposis coli, } \\
\text { hereditary non- } \\
\text { Polyposis colorectal } \\
\text { cancer }\end{array}$ & $\begin{array}{l}\text { Dutch Polyposis coli } \\
\text { organization }\end{array}$ & 200 & 73 & 21 & 8 & 7 \\
\hline $\begin{array}{l}\text { X-linked } \\
\text { agammaglobulinemia }\end{array}$ & $\begin{array}{l}\text { Dutch Immunity disorder } \\
\text { organization }\end{array}$ & 50 & 22 & 3 & 3 & 2 \\
\hline $\begin{array}{l}\text { Spinocerebellar ataxia, } \\
\text { ADCA }\end{array}$ & Dutch Ataxia organization & 50 & 13 & 3 & 2 & 1 \\
\hline Sickle cell anemia & $\begin{array}{l}\text { Dutch Sickle cell anemia } \\
\text { organization }\end{array}$ & 20 & 0 & 0 & 0 & 0 \\
\hline Gaucher disease & $\begin{array}{l}\text { Dutch Gaucher } \\
\text { organization }\end{array}$ & 10 & 0 & 0 & 0 & 0 \\
\hline Cystic fibrosis & $\begin{array}{l}\text { Dutch Cystic fibrosis } \\
\text { organization }\end{array}$ & Website CF & 6 & 5 & 5 & 4 \\
\hline $\begin{array}{l}\text { Hereditary breast cancer } \\
\quad \text { (BCRA-1 and } 2)\end{array}$ & $\begin{array}{l}\text { Dutch Hereditary breast } \\
\text { cancer organization }\end{array}$ & Website BCRA & 6 & 4 & 4 & 3 \\
\hline $\begin{array}{l}\text { Metachromatic } \\
\text { leukodystrophy, } \\
\text { Hunter syndrome, } \\
\text { cystinosis, chronic } \\
\text { granulomatous } \\
\text { disease }\end{array}$ & $\begin{array}{l}\text { Dutch Metabolic disease } \\
\text { organization }\end{array}$ & $\begin{array}{l}\text { Website metabolic } \\
\text { disease organization }\end{array}$ & 6 & 4 & 4 & 2 \\
\hline $\begin{array}{l}\text { X-linked myotubular } \\
\text { myopathy, } \\
\text { SMA type-1 } \\
\text { HMSN-X-linked }\end{array}$ & $\begin{array}{l}\text { Dutch Muscle disease } \\
\text { organization }\end{array}$ & $\begin{array}{l}\text { Website muscle disease } \\
\text { organization }\end{array}$ & 6 & 4 & 4 & 1 \\
\hline Huntington disease & $\begin{array}{l}\text { Dutch Huntington } \\
\text { disease organization }\end{array}$ & $\begin{array}{l}\text { Website Huntington } \\
\text { disease }\end{array}$ & 2 & 2 & 2 & 2 \\
\hline Von Hippel-Lindau & VSOP & Website VSOP & 1 & 1 & 1 & 1 \\
\hline Ehler Danlos disease & VSOP & Website VSOP & 1 & 1 & 1 & 1 \\
\hline Hemophilia & VSOP & Website VSOP & 1 & 1 & 1 & 1 \\
\hline Osteogenesis imperfecta & VSOP & Website VSOP & 1 & 0 & 0 & 0 \\
\hline & TOTAL & 2,892 & 983 & 210 & 127 & 94 \\
\hline
\end{tabular}


